\title{
But I Am Computer Literate: I Passed The Test
}

Annette C. Easton, (E-mail: annette.easton@sdsu.edu), San Diego State University

George Easton, (E-mail: george.easton@sdsu.edu), San Diego State University

Theo Addo, (E-mail: theo.addo@sdsu.edu), San Diego State University

\begin{abstract}
Generic terms such as "computer literacy," "computer competency" and "technology literacy" have been used for decades as measures of one's aptitude with computer and information technology. Many disregarded the ambiguity of these terms while erratic exposure to ever-changing computer technology rendered itself as computer literacy. With an increasing focus on organizations now administering technology literacy tests, educators need to be more cognizant of the computer and information literacy assessments and the implications of these assessments for the core information systems course in business schools.
\end{abstract}

\section{BACKGROUND}

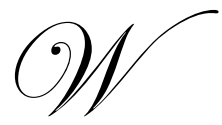

ith the ubiquity and pervasiveness of information and computer technology in our society, it is easy to understand why so many students entering college today consider themselves computer literate. Most of these students grew up with computers in their homes, and most of their computers had Internet connections. The Corporation for Public Broadcasting reported that in 2002, 83\% of American families with children owned a computer and a nearly equal number, $78 \%$, of American families had Internet access ("Connected to the Future, 2003"). Not surprisingly, many of these students have had some experience with computer applications such as word processors, spreadsheets and presentation software since grade school (Plotnikoff, 2003, (Echegaray, 2001).

Furthering students' self-assessed concept of computer literacy has been their exposure, perhaps overexposure, to tightly-coupled technologies and activities such as cell phones, instant messaging, downloading music and computer gaming. The Internet, however, has arguably advanced the digital generation's concept of computer literacy more than any other technology. Students knew how to download MP3 files long before they had an iPod. Many became familiar with instant messaging (IM) on the Internet well before text messaging became feasible on cell phones.

It should not be surprising that the assortment of computer-related skills acquired by many students is often incongruous with the computer skill sets expected in their college study programs, and in the business world (Easton \& Easton, 2003a) (Easton \& Easton, 2003b). For this reason, many business schools still require some type of introductory computer course of their students to ensure their "computer literacy," "computer competency," "technological literacy" or similar term, broadly construed as a measure of one's aptitude and proficiency with computer and information technology. Further, this business school course usually goes beyond basic computer literacy concepts and covers principles of how businesses develop and use information technology.

The disconnect in what business schools expect students to know about business information systems, ("computers" in the mind of the students), and what students think they already know, creates a dilemma in how to develop and teach this content. This disconnect is further exacerbated when students have passed a "computer literacy" test that they thought would exempt them from this course requirement. To this end, our paper presents an overview of the different perceptions of computer literacy, followed by a synopsis of the major assessment tests that are being used to certify literacy levels. Finally we will summarize the implications of these issues towards the 
business school information systems core course.

\section{WHAT IS COMPUTER LITERACY?}

The incongruity issue in perceptions of computer literacy, like those that exist between students and the business school, preceded the personal computer, and yet, is still an issue today. In 1983, in "Stop Saying 'Computer Literacy!'", Harvey indicated that "People who have become accustomed to the [computer] 'literacy' idea find it very difficult even to entertain the question of whether there is any universally required computer experience" (Harvey, 1983). Surprisingly, many educators and practitioners, even today, consider the differences between such generic terms as "computer literacy" and "technological literacy" to be semantically insignificant, if they are considered at all. Unfortunately, this grab-bag of phrases used to explain computer proficiency, experience and usage has become more muddled, and contributes to the problems that we have in developing and teaching the information systems curriculum. Consider the common phrases and associated definitions that contribute to this confusion.

\section{Computer Literacy}

Computer literacy, one of the most commonly used phrases, not surprisingly, is without a standard definition. At the broad end of the scale the definition includes "The ability to use microcomputers confidently for obtaining needed information, solving specific problems, and performing data processing tasks. This includes a fundamental understanding of the operation of microcomputers in general, as well as the use of several types of applications software packages" (Van Vliet, et al, 1994.) At the narrower end of the scale Snyder (2003) suggests that computer literacy means "focusing on only imparting immediately useful skills."

\section{Computer Competency}

Computer competency is another phrase used to describe one's ability to use a computer. This term seems to most often be used by educational institutions that are defining a requirement or proficiency standard. For example, Florida State University has a computer competency requirement that indicates that all students must demonstrate: "basic familiarity with computer hardware, operating systems, and file concepts; working knowledge of a word processor or text editor and at least one other software application (e.g., spreadsheet, database, etc.); and working knowledge of the World Wide Web (WWW) and electronic mail" (http://registrar.fsu.edu/bulletin/undergrad/ info/undergrad_degree.htm\#ComputerSkills.) This can be achieved by taking and passing a designated course, or by taking and passing a skills certification assessment.

\section{Technology Literacy}

Technology literacy is a phrase that encompasses a wider view than simply computer usage. Thomas and Knezek (1995) define technology literacy to include: demystifying technology through conceptual understandings of the underlying science and mathematics principles, operational competence with modern technology systems; The ability to evaluate and use a variety of common technology applications; the ability to innovate and invent ways of applying technology in challenging new situations; an awareness of technology-related careers and of factors critical to success in those careers; and understanding of and sensitivity to societal issues related to technology. Building on this definition, the International Society for Technology in Education (ISTE) created the National Educational Technology Standards (NETS) project to develop a set of technology standards for K-12 grade levels. The specific performance indicators vary by grade level but are grouped according to the following categories: Basic operations and concepts; Social, ethical and human issues; Technology productivity tools; Technology communications tools; Technology research tools; Technology problem-solving and decision-making tools (http://cnets.iste.org/students/pdf/ NETSS_standards.pdf.)

\section{Information Literacy}

Information literacy is a phrase that is most commonly associated with the American Library Association (ALA). Information literacy is defined as the "set of abilities requiring individuals to recognize when information is 
needed and have the ability to locate, evaluate, and use effectively the needed information" (http://www.ala.org/ala/acrl/acrlstandards/standards.pdf.). Operationalizing this definition, the Information Literacy Competency Standards for Higher Education have stated that an information literate person: Determines the extent of information needed; Accesses the needed information efficiently and effectively; Evaluates information and its sources critically and competently; Incorporates information effectively to accomplish a specific purpose; and Understands the economic, legal, and social issues surrounding the use of information (http://www.ala.org/ ala/acrl/acrlstandards/standards.pdf.) Understandably, with the increase in the availability and use of electronic sources, information literacy requires a certain amount of information technology skills (literacy.) Although the ALA recognizes the distinction between the two literacies, educators and students don't always understand the differences.

\section{Computer Fluency}

Computer fluency is a relatively new phrase in this area. Snyder (2003) states that computer fluency contains computer literacy (defined as immediately useful skills) but adds problem solving, reasoning, complexity management, and other higher-level thinking processes, as well as a broader coverage of technological topics that prepare students to keep pace with the ever-advancing technology.

Finally, the latest entrant into this grab-bag of phrases is "Information and Communications Technology (ICT) Literacy". Rockman et. al. (2005) define ICT literacy as the "ability to use digital technology, communication tools, and/or networks to access, manage, integrate, evaluate, create, and communicate information ethically and legally in order to function in a knowledge society." ICT literacy is viewed as a link between technical literacy (Can I add a record into a database?) and information literacy (Can I locate information?)

As you read the definitions associated with these six phrases that all have some association with computers, it is easy to see how students and faculty may have different views of how proficient students are, and need to be, related to information systems for business. Unfortunately, with the increase in the availability and usage of computer literacy assessment, this disconnect will be more apparent. Faculty will increasingly be challenged to accept the passing of an assessment test in place of the introductory information systems course. As a result, educators need to become more cognizant of the computer and information literacy debate and of the various methods being used to certify literacy levels.

\section{THE COMMON ASSESSMENTS}

There are a variety of assessments that have been developed to assess computer literacy. The Microsoft Office assessments have been around for many years, while others like the ICT assessment have just been introduced. In order to effectively evaluate the applicability of these assessments, faculty need to be educated about the goal, format and implementation of each assessment.

\section{Microsoft Office Specialist Exams (MOS)}

The MOS exams are designed to evaluate overall comprehension of Office programs. The assessments are customized by product and are offered at the core and expert level. For the core Excel test, as example, the skill sets tested include creating data and content, analyzing data, formatting data and content, collaborating, and managing workbooks. They include both the ability to use advanced features and the ability to integrate the Office programs with other software programs. Microsoft states that the exams are designed to measure one's ability to perform specific real-world job functions and provide a consistent measure of technical proficiency and expertise. A typical exam is about one hour and the questions are performance-based using either a live Microsoft application or a simulated Microsoft application environment. The usage of the exams is targeted towards employers so that they can easily determine employee skill certification. The American Council on Education (ACE) has issued a one-semester hour college credit recommendation for passing each of the Office Specialist exams, although each university retains the right to decide whether to accept the certification for credit or course equivalency. Additional details about the MOS exams can be found at: http://www.microsoft.com/learning/mcp/officespecialist/default.asp. 


\section{Internet And Computing Core Certification $\left(\mathrm{IC}^{3}\right)$}

The $\mathrm{IC}^{3}$ certification is designed to assess skills in three main areas: computing fundamentals (hardware, software and operating systems), key applications (common functions, word processing, spreadsheets, and presentation software), and living online (networks and the internet, email, using the internet, and the impact of computing and the internet on society.) To achieve certification one must pass the three exams. Each exam is about one hour and contains a mixture of objective and performance-based questions. The usage of the exams is targeted towards anyone who wants a working knowledge about computers and the internet. It is also promoted as a first step in certification programs. The ACE has also recommended the $\mathrm{IC}^{3}$ for college credit. Additional details about the $\mathrm{IC}^{3}$ certification can be found at: http://info.certiport.com/yourpersonalpath/ic3Certification/.

\section{International Computer Driving License (ICDL)}

The ICDL, promoted as the "worldwide standard for computer literacy", has been designed as a vendor neutral test to assess a basic level of skill. To earn an ICDL a student must pass one theoretical and six practical tests. The seven tests or modules include basic concepts of IT, using the computer and managing files, word processing, spreadsheets, databases, presentations, and information and communication. The typical exam lasts 45 minutes. The exam questions are practice-based for the applications modules. The usage of the exams is targeted toward the general public who want to use a personal computer competently and towards office workers who want formal certification. Additional details about the ICDL certification can be found at: http://www.ecdl.com/main/index.php. Note: Within Europe this test is known as the European Computer Driving License (ECDL).

\section{Textbook/Publisher Products}

Several of the publishers of computer literacy textbooks for the university market have created online training and assessment products. These products include Skills Assessment Manager (SAM) by Course Technology, SIMNET by McGraw-Hill and Train and Assess IT by Prentice Hall. In general all of these products are geared towards the same sets of skills assessed by the Microsoft Office Specialist exams, although they also have online training portions that students may access. Some of the products also allow the capability to assess computer concepts. Instructors can designate how many questions they wish to include on an assessment so there is no standard exam time. The exam questions are based on students performing actual tasks (like copying a formula in a cell) in a simulated application environment. The usage of the exams is geared more towards individual faculty or colleges to be able to devise training and assessment that meets their requirements. Additional details about these products can be found at: http://samcentral.course.com/default.cfm, http://www.mhhe.com/cit/simnet/, and http://esminfo. prenhall.com/taitdemo/.

\section{Information And Communications Technology (ICT) Assessment}

Developed by Educational Testing Service (ETS) and a collaboration of universities specifically for the higher education environment, the ICT assessment was designed to assess students' proficiencies related to "their ability to use technology as a tool to research, organize, evaluate, and communicate information, and their possession of a fundamental understanding of the ethical/legal issues surrounding the access and use of information." Specifically, tasks have been developed to look at skills in seven different proficiencies: define, access, manage, integrate, evaluate, create, and communicate. There are two difficulty levels of the test, although each test does include tasks for all seven proficiencies. The Core Level is designed for the entering freshman while the advanced level is designed for juniors. The assessment lasts about 75 minutes. The exam questions are scenario-based and may involve several different steps and/or tools. The usage of the exam is targeted to the higher education environment. Additional details about the ICT assessment can be found at: http://www.ets.org/ictliteracy.

For the most part these tests do accurately assess their intended objective. However, there are some general caveats that need to be considered when interpreting the results of most of these assessments. First, many of the assessments use a simulated environment to assess the application skills. In general this works fine, however if all known shortcut methods have not been programmed into the system, a student may have a correct answer but be 
marked incorrect in their response. Second, tools-based assessments tend to focus on keystrokes and knowing how to accomplish a task within a product - not how or when to utilize a tool to solve a problem. Third, concepts-based assessments tend to focus on basic vocabulary about a computer - not how to think strategically about using IT in business. Finally, the newer assessments are trying to evaluate critical-thinking and problem-solving skills, but the skills being assessed are based more on "entry-level" tasks.

\section{IMPLICATIONS FOR THE BUSINESS SCHOOL CURRICULUM}

Unfortunately, the biggest issue is that these assessments don't evaluate computer literacy in the context of the business school environment. As mentioned earlier, most business schools require a core introductory computer course as part of the business degree requirement. Often this course is titled Fundamentals of Information Technology or Principles of Information Systems. While the exact content varies, it typically goes beyond basic computer literacy concepts and covers principles of how businesses develop and use information technology as well as an introduction to common productivity tools. As a result, even for those assessment that include more than just application skills, the focus tends to be on basic concepts of computer literacy (i.e. what is a hard drive?) instead of the development and use of information systems in business. As such, these assessment tools may be more appropriate to help standardize a minimum level of literacy for entering the course.

To stay relevant, and to help avoid misunderstandings, faculty must continue to monitor and adapt the content of their core Information Systems course required of all business majors. In addition to evolving as the incoming technology literacy of our students increases, we must determine if we are really teaching the right content What every business student needs to know about Information Systems? Zmud et al. (2002) put forward three issues to help frame the appropriate content of this core course: 1) providing "software tools" expertise to students is not central to the mission of the IS faculty and IS curriculum; 2) tools are only tangentially related to the strategic role that information systems play in organizations; and 3) core concepts related to information systems are essential for a wellrounded business school graduate. To accomplish this Zmud et al. (2002) recommend 10 key information systems concepts to be covered in this core course. These concepts include:

- What are information systems?

- How do information systems influence organizational competitiveness?

- Why have databases become so important to modern organizations?

- Why are technology infrastructures so important to modern organizations?

- What is the role of the Internet and networking technology in modern organizations?

- What are the unique economics of information and information systems?

- How do information systems enable organizational processes?

- How do organizations develop, acquire, and implement information systems?

- What is the nature of IS management?

- What ethical, criminal and security issues do organizations face when using information systems?

When most IS faculty review Zmud's list, it is usually clear to them that these concepts are not currently assessed through any of the available assessment tools. IS faculty's challenge then is to ensure that the content covered in our core course is beyond the basic skill level that can be adequately assessed via an established exam. We must find innovative teaching materials that support an integrated view of technology and business. With appropriate content and teaching materials, we will then be able to clearly articulate to both our college of business colleagues and to our students what these concepts are, why they are important, and how they are not being assessed in any of the available tests.

\section{BIBLIOGRAPHY}

1. Computer Skills Competency, in 2005 - 2006 General Bulletin-HTML Version. Retrieved October 20, 2005 from http://registrar.fsu.edu/bulletin/undergrad/info/undergrad_degree.htm\#ComputerSkills.

2. Connected to the Future, (2003). The Corporation for Public Broadcasting. Retrieved February 2, 2004 from http://www.cpb.org/ed/resources/connected/. 
3. Echegaray, C. (2001, February 9). PowerPoint pros 6th-graders to teach adults about computers:[RT. 9 WEST Edition]. Telegram \& Gazette. Worcester, Mass. pp. B.1.

4. Easton, A. and Easton, G. (2003a). Closing the Gap: Proficiency vs. Perception, International Business and Economics Research Journal, 2(10), pp. 11-14.

5. Easton, G. and Easton, A. (2003b). Assessing Computer Literacy: A comparison of self-assessment and actual skills, in McGill, Tanya, ed., Current Issues in IT Education, (pp. 238-254) IRM Press.

6. Harvey, Brian. (1983). Stop Saying 'Computer Literacy!' University of California, Berkeley. Retrieved February 6, 2005 from http://www.cs.berkeley.edu/ bh/stop.html

7. Information Literacy Competency Standards for Higher Education. (2000.) Retrieved October 19, 2005 from http://www.ala.org/ala/acrl/acrlstandards/standards.pdf.

8. Ives, B., J. Valacich, R. Watson, R. Zmud, et al. (2002). What every business student needs to know about information systems? Communications of the Association for Information Systems, Vol. 9, pp. 467-477.

9. Microsoft Office Specialist Certification Requirements. (September 8, 2004). Retrieved October 19, 2005 from http://www.microsoft.com/learning/mcp/officespecialist/requirements.asp.

10. NETS for Students. Retrieved October 20, 2005 from http://cnets.iste.org/students/pdf/NETSS_standards .pdf.

11. Plotnikoff, D. (2003, May 18). Growing up wired: When technology is just a part of everyday life. Mercury News. Retrieved March 26, 2004, from http://www.mercurynews.com/mld/mercurynews/business /special_packages/wired_kids/5889282.htm

12. Snyder, L. (2003). Fluency with Information Technology: Skills, Concepts, \& Capabilities. Boston: AddisonWesley.

13. Thomas, L.G. and D.G. Knezek. (1995). Technology Literacy for the Nation and for Its Citizens. Retrieved October 20, 2005 from the International Society for Technology in Education web site: http://www.iste.org/Content/NavigationMenu/Research/Reports/Technology_Literacy_White_Paper_1995_/ Technology_Literacy_for_the_Nation_and_for_Its_Citizens.htm

14. Young, Jeffrey R. (2004). Testing Service to Unveil as Assessment of Computer and Information Literacy. Chronicle of Higher Education, 11/12/2004, Vol. 51, Issue 12.

15. Zeller Jr., Tom. (2005, Jan 17). Measuring Literacy in a World Gone Digital. The New York Times. (Late Edition, East Coast). pg. C.1.

16. Rockman, I., G. Smith, and I. Katz. (2005). An Overview of the Design and Architecture for the ICT Literacy Assessment (PPT) as presented at American Library Association Annual Conference, Chicago, June 26, 2005. Retrieved October 15, 2005 from http://www.ets.org/ictliteracy. 